\title{
Effect of Potato By-Product on Production Responses of Dairy Cows and Total Mixed Ration Stability
}

\author{
Marcia Franco*D, Tomasz Stefański (D), Taina Jalava, Marja Lehto, Minna Kahala (D), Eila Järvenpää (D), \\ Päivi Mäntysaari and Marketta Rinne (D)
}

Natural Resources Institute Finland (Luke), FI-31600 Jokioinen, Finland; tomasz.stefanski@luke.fi (T.S.); taina.jalava@luke.fi (T.J.); marja.lehto@luke.fi (M.L.); minna.kahala@luke.fi (M.K.); eila.jarvenpaa@luke.fi (E.J.); paivi.mantysaari@luke.fi (P.M.); marketta.rinne@luke.fi (M.R.)

* Correspondence: marcia.franco@luke.fi; Tel.: +358-295-322-108

check for updates

Citation: Franco, M.; Stefański, T.; Jalava, T.; Lehto, M.; Kahala, M.; Järvenpää, E.; Mäntysaari, P.; Rinne, M. Effect of Potato By-Product on Production Responses of Dairy Cows and Total Mixed Ration Stability. Dairy 2021, 2, 218-230. https://doi.org/10.3390/dairy2020019

Academic Editors: Burim Ametaj and F. Javier Giráldez

Received: 29 December 2020

Accepted: 19 April 2021

Published: 23 April 2021

Publisher's Note: MDPI stays neutral with regard to jurisdictional claims in published maps and institutional affiliations.

Copyright: (c) 2021 by the authors. Licensee MDPI, Basel, Switzerland. This article is an open access article distributed under the terms and conditions of the Creative Commons Attribution (CC BY) license (https:// creativecommons.org/licenses/by/ $4.0 /)$.

\begin{abstract}
Vegetable by-products have great potential for use as animal feeds and thus could improve the sustainability of the food system. The objective was to evaluate the milk production potential of potato by-product (PBP) replacing cereal grains in grass silage-based total mixed ration (TMR). Additionally, a laboratory scale experiment was conducted to assess the effect of PBP and chemical preservatives on the aerobic stability of TMRs. A change-over dairy cow feeding experiment was conducted to evaluate the inclusion of $135 \mathrm{~g} / \mathrm{kg}$ (on a dry matter (DM) basis) of PBP in TMR. Additionally, the aerobic stability of TMR was evaluated by preparing TMRs with increasing levels of PBP and treated with different doses of formic and propionic acid or salt-based preservatives. The inclusion of PBP in dairy cow diets decreased feed intake, but organic matter digestibility was greater in the PBP diet, resulting in only slightly decreased production (milk protein 1435 vs. $1363 \mathrm{~g} /$ day, $p<0.05$; milk lactose 1716 vs. $1606 \mathrm{~g} /$ day, $p<0.05$ ). The aerobic stability of TMR was negatively affected by the inclusion of PBP, but it could to a limited extent be prolonged using chemical preservatives. The inclusion of PBP decreased feed intake and milk production to some extent when included in the diet of high-producing dairy cows. The utilization of PBP may, however, be justified from a sustainability point of view, as it provides a way to circulate the nutrients of a non-human edible feed material back into the food chain.
\end{abstract}

Keywords: aerobic stability; animal feed; bio-waste utilization; preservative; Solanum tuberosum; starch; sustainability; valorization; vegetable by-product

\section{Introduction}

The sustainability of food systems has gained increasing concern in the agricultural sector. Approximately 88 million tons of food waste is generated annually in Europe [1], which includes both edible food and inedible parts associated with food. Bio-waste utilization as livestock feed is an ecologically viable and economically effective method of by-product management because the costs are reduced and, instead of being disposed of in landfill, the nutrients are recycled [2]. The long traditions of using by-products from various food, beverage and bioenergy industries contribute to the sustainability of livestock production, but accurate information on the quality of the side streams is essential to improve the efficiency of their use [3].

Potato (Solanum tuberosum) is the world's most used non-grain food commodity [4]. Europe has the highest level of potato consumption in the world (almost $90 \mathrm{~kg}$ per capita per year) [4] and potatoes account for approximately $2 \%$ of the world's dietary energy supply [5], resulting in a large amount of potato by-products (PBP) being generated. Potato by-products represent a great potential for use as an animal feed [6], if aspects related to feed safety, feed value, animal performance and palatability can be solved. Potato contains glycoalkaloids (solanine and chaconine), anti-nutritional factors that can cause neurological disorders in humans, but not in ruminants if intake of potato is below $30 \%$ of the dietary 
dry matter (DM) $[7,8]$. The use of vegetable by-product streams instead of, e.g., cereal grains would increase the amount of non-human edible components in animal diets [9], which would improve the acceptance of animal production.

Bakshi et al. [8] emphasized the safety issues related to moist by-product feeding but encouraged research to find ways to incorporate them into livestock diets to increase feed supply and sustainability. Potato or potato by-product inclusion in ruminant diet has been investigated for decades, with a range of inclusion levels and different responses to production parameters [8]. The milk production responses varied from slight decreases [10], to no differences [11,12], to slight increases [13] depending on the quality of feeds they replaced in the diets used. The use of moist, easily perishable vegetable by-products such as PBP is challenged by their fast deterioration [14]. Preservatives can be added to materials to improve quality, such as increasing aerobic stability [15], which allows for more efficient logistics.

The aim of this study was to evaluate the potential of a PBP when replacing cereal grains in a grass silage-based total mixed ration (TMR) of high-yielding dairy cows. Further, a laboratory-scale experiment was conducted to assess the effect of PBP and chemical preservatives on the aerobic stability of TMRs.

\section{Materials and Methods}

The experiments were conducted at Natural Resources Institute Finland (Luke) in Jokioinen, Finland $\left(60^{\circ} 48^{\prime} \mathrm{N}, 23^{\circ} 29^{\prime} \mathrm{E}\right)$.

\subsection{Dairy Cows Fed Potato By-Product (Experiment 1)}

The PBP originated from a potato peeling company (Kiviranta, Loimaa, Finland) and it was comprised of unheated potato peels and discarded whole potatoes. Approximately one ton of fresh PBP was collected once a week for six consecutive weeks during April and May in 2019. The PBP was transported in plastic IBC containers and $51 /$ ton of a formic and propionic acid-based preservative (AIV Ässä Na, Eastman, Oulu, Finland) was added to it to extend the preservation period [15]. The container as well as the TMRs after preparation were stored in an uninsulated barn and the average temperature was ca. $+10^{\circ} \mathrm{C}$. The grass silage used was made of a second cut of timothy-meadow fescue sward, slightly prewilted, precision chopped and ensiled in a horizontal silo using $5 \mathrm{l} /$ ton of a formic acid-based additive (AIV2; Eastman, Oulu, Finland). Two concentrate mixtures were prepared to be used in the control diet and to complement the PBP, respectively. The concentrate mixtures were pelleted to aid even mixture in TMR. The TMR was mixed twice a week (Pellon Cutmix; Pellon Group Oy, Ylihärmä, Finland) and delivered to cows four times daily (8:00, 13:00, 16:15 and 18:00 h).

The use of animals in scientific experimentation was in line with Directive 2010/63/EU. No invasive research methods were used so that a formal license was not required according to the National Ethics Committee (Hämeenlinna, Finland). Ten Nordic Red cows (125 \pm 57 days in lactation and $37 \pm 5.3 \mathrm{~L}$ milk per day for control treatment, and $127 \pm 53$ days in lactation and $38 \pm 3.9$ L milk per day for PBP treatment) in the beginning of the experiment were used in a 2-period change-over experimental design. Five cows were allocated to a control treatment without PBP and five cows received $135 \mathrm{~g} / \mathrm{kg}$ PBP in a TMR on a DM basis. After the period of sample collection and evaluation of animal response, the cows switched the treatments. Cows were housed in a free-stall barn with individual beds, individual access to diet and free access to water. Cows were fed TMR ad libitum in a 0.5:0.5 silage:concentrate ratio, allowing 0.05 for leftovers. Additionally, ca. $550 \mathrm{~g}$ per cow per day of the control concentrate used in TMR was given in the milking parlor. Diets were formulated to meet nutrient requirements according to Luke [16]. An amount of $135 \mathrm{~g} / \mathrm{kg}$ PBP was defined considering the absence of major differences between nutritional requirements and provision of nutrients in the diet. The PBP replaced part of the concentrate in the TMR for the PBP group. Composition of the experimental diets are presented in Table 1. 
Table 1. Composition of the total mixed rations (TMR) in the dairy cow feeding experiment (Experiment 1).

\begin{tabular}{ccc}
\hline & \multicolumn{2}{c}{ TMR Composition, g/kg Dry Matter } \\
\cline { 2 - 3 } & Control & Potato By-Product \\
\hline Barley & 110 & 50 \\
Oats & 85 & 39 \\
Wheat & 50 & 25 \\
Molassed sugar beet pulp & 65 & 63 \\
Rapeseed meal & 175 & 175 \\
Minerals & 15 & 13 \\
Potato by-product & 0 & 135 \\
Grass silage & 500 & 500 \\
\hline
\end{tabular}

Each experimental period lasted three weeks and the third week was used for data and sample collection. Intake and milk yield were evaluated on a daily basis. Cows were milked twice daily (6:00 and 16:00 h) in a milking parlor and milk yield was gravimetrically recorded (Pellon SAC, Kolding, Denmark). Feed intake was measured by weighing daily the amount of both TMRs and leftovers individually per cow, and adding the amount of concentrate given in the milking parlor. Four samples of milk were taken in the last two days (morning and evening) of each period and separately analyzed in order to evaluate the composition. The results presented are the weighted means taking into consideration the different amount of milk produced at each of the milkings. Fecal grab samples were taken in the last three days of each period after morning and evening milking for diet digestibility determination [17].

Samples of feeds were taken daily during the third week of both periods. Samples of silage and PBP were evaluated for DM $\left(105^{\circ} \mathrm{C}\right.$ for $\left.16 \mathrm{~h}\right)$, ash (method 942.05, [18]), crude protein (CP; method 968.06, [18]), water soluble carbohydrates (WSC; [19]), starch [20], neutral detergent fiber (NDF; [21]), indigestible NDF (iNDF; [22]), cellulase solubility [23], $\mathrm{pH}$, ammonia [24], lactic acid [25] and VFA [26]. Neutral detergent fiber was determined using filter bag technique (25-micron nylon bags F57, ANKOM Technology, Macedon, NY, USA) and ANKOM 220 Fiber Analyzer (ANKOM Technology, Macedon, NY, USA) [21] including $\alpha$-amylase. Ethanol was measured using the spectrophotometric method of Roche Diagnostics (Basel, Switzerland; application Ethanol, UV-method, kit Cat. No. 10176290 035). The analysis was made from water extract of the sample (1:15). The equipment used was UV-VIS double-beam UV-1800 spectrophotometer (Schimadzu Co., Kyoto, Japan). Concentrates were analyzed for DM, ash, CP, starch, NDF and iNDF. Fecal samples were analyzed for DM, ash, CP, NDF, starch and iNDF. Feed samples were also analyzed for enterobacteria, lactic acid bacteria, yeasts, molds, total bacteria and Clostridia, as described by Rinne et al. [15], at the beginning of the experiment and at the end of both experimental periods. The laboratory's quality management system follows the standard SFS-EN ISO/IEC 17025:2017 and is accredited by FINAS (the Finnish Accreditation Service, Helsinki, Finland) with number T024. The in vitro organic matter (OM) digestibility of silage was calculated according to Huhtanen et al. [23], while metabolizable energy (ME), metabolizable protein (MP) and protein balance in rumen (PBV) were calculated according to Luke [16]. The ME intake of the cows was calculated based on feed values and using the correction equation or calculating from the amount of digestible OM intake using a value of 16 MJ ME per kg organic matter digested [16].

Data were analyzed using a MIXED procedure (SAS Inc. 2002-2012, Release 9.4; SAS Inst. Inc., Cary, NC, USA) according to the statistical model: $Y_{i j k}=\mu+T_{i}+C_{j}+P_{k}+e_{i j k}$, where $Y_{i j k}$ is the observation of the dependent variable ijk; $\mu$ is the overall mean of the population; $T_{i}$ is the treatment fixed effect; $C_{j}$ is the random effect of cow; $P_{k}$ is the random effect of period; and $\mathrm{e}_{\mathrm{ijk}}$ is the random error associated with the observation ijk. The UNIVARIATE procedure was used to test the normal distribution of data through Shapiro- 
Wilk test. Least squares means and standard error of the means (SEM) were reported per treatment. Significant difference was declared at $p<0.05$.

\subsection{Aerobic Stability of Total Mixed Ration and Potato By-Product (Experiment 2)}

For the evaluation of aerobic stability at laboratory-scale, three TMRs were prepared with increasing levels of PBP. The same PBP as used in the dairy cow experiment was used. All TMRs contained 50\% grass silage and PBP was used at 0,10 and 20\% of total DM in TMR1, TMR2 and TMR3, respectively. To maintain the DM constant among the 3 TMRs, water was proportionally added into TMR1 and TMR2. Samples of silage, concentrate and PBP were taken and analyzed for DM, pH, ash, CP, NDF, starch, WSC and microbial quality according to the methodology described in the previous section.

The TMRs were treated with a formic and propionic acid-based preservative (FPA; AIV Ässä Na, Eastman, Oulu, Finland; composition $580 \mathrm{~g} / \mathrm{kg}$ formic acid, $200 \mathrm{~g} / \mathrm{kg}$ propionic acid, $25 \mathrm{~g} / \mathrm{kg}$ potassium sorbate and $52 \mathrm{~g} / \mathrm{kg}$ sodium formate) and a salt-based preservative (Salt; Xtrasil Majs HD, Konsil Scandinavia AB, Tvååker, Sweden; composition $225 \mathrm{~g} / \mathrm{kg}$ sodium benzoate, $35 \mathrm{~g} / \mathrm{kg}$ potassium sorbate and $50 \mathrm{~g} / \mathrm{kg}$ ammonium propionate). Both preservatives were used at 1.5 and $3 \mathrm{~L}$ per ton (FPA1, FPA2, Salt1 and Salt2, respectively), and a control treatment without any preservative was included. The preservatives were diluted in tap water in order to have an even application, while for the control treatment, the same volume of tap water was applied.

The experiment comprised 15 treatments ( 3 TMRs $\times 5$ preservatives) that were studied in 3 replicates. Approximately $700 \mathrm{~g}$ of TMR was weighed into polystyrene boxes and aerobic stability by rise in temperature was evaluated. The temperature measurements were carried out using a MicroLite USB Data Logger from Fourtec (Chicago, IL, USA), where thermocouple probes inserted into the samples in polystyrene boxes were connected to the MicroLite devices. Temperature was automatically recorded at 10 -min intervals. Aerobic stability was defined as the time taken to increase the temperature of the sample by $2{ }^{\circ} \mathrm{C}$ (or $3{ }^{\circ} \mathrm{C}$ ) above the ambient temperature. Samples were weighed before and after the aerobic incubation to determine the aerobic losses over 10 days.

The aerobic spoilage of the samples was also evaluated through visual inspection. The TMRs were placed into plastic containers, which were covered with perforated plastic film and kept at $+20{ }^{\circ} \mathrm{C}$. Visual inspection was conducted once daily by observing the growth of yeasts and molds on the surface of the TMR using a scale: $0=$ no mold, $1=$ slight moldiness, 2 = moderate moldiness and $3=$ severe moldiness. Samples were discarded when severely molded. The result of this test was the number of days the samples remained unmolded and slightly molded.

Aerobic stability of PBP as such was also evaluated through visual inspection, since rise in temperature is not a suitable method for such wet material [27]. Potato by-product was weighed into plastic containers and preservatives were carefully mixed with it. In order to evaluate dose response to chemical preservatives, five treatments were applied as previously described for TMR.

Data were analyzed using a MIXED procedure (SAS Inc. 2002-2012, Release 9.4; SAS Inst. Inc., Cary, NC, USA) according to the statistical model: $Y_{i j}=\mu+T_{i}+P_{j}+\left(T_{i} \times P_{j}\right)+e_{i}$, where $Y_{i j}$ is the observation of the dependent variable $i j ; \mu$ is the overall mean of the population; $T_{i}$ is the fixed effect of TMR treatment; $P_{j}$ is the fixed effect of preservative treatment; $\left(T_{i} \times P_{j}\right)$ is the fixed effect of the interaction between TMR and preservative treatments; and $\mathrm{e}_{\mathrm{ij}}$ is the random error associated with the observation $\mathrm{ij}$. The UNIVARIATE procedure was used to test the normal distribution of data through Shapiro-Wilk test. Least squares means and standard error of the means (SEM) were reported per treatment. Significant difference was declared at $p<0.05$. The sum of squares was further partitioned into contrasts to evaluate the linear and quadratic effects of proportion of PBP and the dose response to the preservatives. Significant difference was declared at $p<0.05$. 


\section{Results and Discussion}

\subsection{Dairy Cows Fed Potato By-Product (Experiment 1)}

The chemical composition and feed values of the feeds in the dairy cow experiment are shown in Table 2. The basal grass silage was of good nutritional and hygienic quality. The values for the PBP reflected closely the values of whole potato given in Luke [16] and Feedipedia [28] and indicate that in the peeling process, a lot of potato was included in the PBP. The PBP had a much higher starch content than the concentrates and a high energy value, but the protein values were lower due to the low $\mathrm{CP}$ content of it.

Table 2. Chemical composition, fermentation quality and feed values of the feeds used in the dairy cow feeding experiment (Experiment 1).

\begin{tabular}{|c|c|c|c|c|}
\hline & \multirow{2}{*}{$\begin{array}{l}\text { Grass } \\
\text { Silage }\end{array}$} & \multicolumn{2}{|c|}{ Concentrates } & \multirow{2}{*}{$\begin{array}{c}\text { Potato } \\
\text { By-Produc }\end{array}$} \\
\hline & & Control & Experimental & \\
\hline Dry matter (DM), g/kg & 343 & 885 & 886 & 202 \\
\hline \multicolumn{5}{|l|}{ In DM, g/kg } \\
\hline Ash & 97 & 74 & 90 & 49 \\
\hline Crude protein & 140 & 213 & 240 & 85 \\
\hline Water soluble carbohydrates & 110 & 73 & 85 & 104 \\
\hline Starch & 6 & 177 & 177 & 626 \\
\hline Neutral detergent fiber & 499 & 231 & 235 & 53 \\
\hline Indigestible neutral detergent fiber & 85 & 65 & 65 & 5 \\
\hline \multicolumn{5}{|l|}{ Fermentation quality } \\
\hline $\mathrm{pH}$ & 4.34 & & & 3.95 \\
\hline Ethanol, g/kg DM & 2.9 & & & 0.4 \\
\hline Ammonia N, g/kg N & 31 & & & 4 \\
\hline Lactic acid, g/kg DM & 34 & & & 4 \\
\hline Acetic acid, g/kg DM & 14 & & & 5 \\
\hline Propionic acid, g/kg DM & 0.7 & & & 7.5 \\
\hline Butyric acid, g/kg DM & 0.15 & & & 0.03 \\
\hline \multicolumn{5}{|l|}{ Feed values } \\
\hline In vitro organic matter digestibility, $g / g$ & 0.770 & & & \\
\hline Metabolizable energy, MJ/kg DM & 11.1 & 11.6 & 11.2 & 12.1 \\
\hline Metabolizable protein, g/kg DM & 83 & 115 & 124 & 87 \\
\hline Protein balance in the rumen, $\mathrm{g} / \mathrm{kg} \mathrm{DM}$ & 17 & 41 & 69 & -46 \\
\hline
\end{tabular}

The microbial quality of feeds and TMRs fed to dairy cows is presented in Table 3. The microbial quality of the individual feeds was numerically better than the final TMRs offered to cows. The microbial quality of the TMR containing PBP was similar to Control immediately after preparation. In the production trial, the development of hygienic quality of the TMR or the quality of the PBP over the one-week storage period were not determined. Based on Experiment 2, storage time may pose a risk in terms of faster deterioration of the TMR with PBP, which might be reflected in decreased intake. However, in this case a formic acid-based preservative was used to prolong the shelf-life of PBP, and no fluctuations in feed intake nor subjective signs of deterioration were observed either in respect to TMR storage time or within the one-week storage period of each PBP batch. 
Table 3. Microbial quality of feeds and total mixed rations (TMR) used in the dairy cow feeding experiment (Experiment 1).

\begin{tabular}{|c|c|c|c|c|c|c|}
\hline & \multirow{2}{*}{ Grass Silage } & \multicolumn{2}{|c|}{ Concentrates } & \multirow{2}{*}{$\begin{array}{c}\text { Potato } \\
\text { By-Product }\end{array}$} & \multicolumn{2}{|c|}{ TMRs } \\
\hline & & Control & Experimental & & Control & Experimental \\
\hline Enterobacteria, cfu ${ }^{1} / \mathrm{g}$ & $1.0 \times 10^{1}$ & $2.2 \times 10^{3}$ & $7.7 \times 10^{3}$ & $1.2 \times 10^{1}$ & $6.4 \times 10^{5}$ & $5.6 \times 10^{3}$ \\
\hline Lactic acid bacteria, cfu/g & $3.7 \times 10^{6}$ & $2.6 \times 10^{5}$ & $6.1 \times 10^{5}$ & $8.3 \times 10^{6}$ & $1.8 \times 10^{7}$ & $1.1 \times 10^{7}$ \\
\hline Aerobic bacteria, cfu/g & $3.5 \times 10^{5}$ & $1.6 \times 10^{5}$ & $5.8 \times 10^{5}$ & $2.6 \times 10^{6}$ & $2.6 \times 10^{6}$ & $7.2 \times 10^{5}$ \\
\hline Yeasts, cfu/g & $5.8 \times 10^{4}$ & $1.3 \times 10^{3}$ & $<1.0 \times 10^{1}$ & $5.6 \times 10^{3}$ & $8.5 \times 10^{4}$ & $1.4 \times 10^{4}$ \\
\hline Molds, cfu/g & $<1.0 \times 10^{1}$ & $6.8 \times 10^{4}$ & $1.4 \times 10^{4}$ & $<1.0 \times 10^{1}$ & $6.0 \times 10^{4}$ & $3.1 \times 10^{4}$ \\
\hline Clostridia, spore/g & 5 & 10 & 96 & 3 & 43 & 42 \\
\hline
\end{tabular}

${ }^{1} \mathrm{cfu}$ : colony-forming unit.

The inclusion of PBP in dairy cow diets resulted in lower $(p<0.05)$ feed and nutrient intakes (Table 4). Consequently, the daily nutrient intakes of $\mathrm{OM}, \mathrm{CP}$ and NDF were lower $(p<0.05)$ than in the control diet, but due to the high starch content of PBP, the starch intake was higher $(p<0.05)$ in the PBP diet. The OM, CP, NDF and iNDF intakes were lower in the diet containing PBP, while the starch intake was higher ( $3.91 \mathrm{vs.} 2.54 \mathrm{~kg} /$ day; $p<0.05$ ). The reduced intakes might have been due to a greater starch content in the diet containing PBP, as reported by Lechartier and Peyraud [29]. This contrasts with Onwubuemeli et al. [30], who reported no difference in dry matter intake when feeding dairy cows with wet potato processing waste up to $20 \%$ of the diet on a dry matter basis. The lower CP concentration was due to the lower $\mathrm{CP}$ concentration in PBP compared to the cereals it replaced in the diet. We decided not to compensate for that by adding more rapeseed meal into the PBP diet and thus confound the effects of PBP and rapeseed meal inclusion. A similar MP concentration in the diet and a clearly positive PBV value for the PBP diet suggest that the diets were not deficient in protein and the small difference in diet protein concentration probably did not influence the results obtained from this experiment.

Table 4. Feed and nutrient intake, and nutrient concentrations of the total mixed ration (TMR) diets in the dairy cow feeding experiment (Experiment 1).

\begin{tabular}{|c|c|c|c|c|}
\hline & Control TMR & Potato By-Product TMR & SEM $^{1}$ & $p$-Value \\
\hline \multicolumn{5}{|l|}{ Feed intake, kg dry matter/day } \\
\hline Total & 28.3 & 26.3 & 0.21 & $<0.01$ \\
\hline Forage & 13.9 & 12.9 & 0.11 & $<0.01$ \\
\hline Concentrate & 14.4 & 9.9 & 0.10 & - \\
\hline Potato & 0 & 3.5 & 0.08 & - \\
\hline \multicolumn{5}{|l|}{ Nutrient intake/day, kg } \\
\hline Organic matter & 25.4 & 23.5 & 0.20 & $<0.01$ \\
\hline Crude protein & 4.90 & 4.36 & 0.038 & $<0.01$ \\
\hline Starch & 2.54 & 3.91 & 0.050 & $<0.01$ \\
\hline Neutral detergent fiber & 10.1 & 8.8 & 0.08 & $<0.01$ \\
\hline Indigestible neutral detergent fiber & 2.08 & 1.72 & 0.015 & $<0.01$ \\
\hline Protein balance in the rumen & 827 & 743 & 5.9 & $<0.01$ \\
\hline \multicolumn{5}{|l|}{ Nutrient concentration in the diet, $\mathrm{g} / \mathrm{kg}$} \\
\hline Organic matter & 897 & 893 & 0.3 & $<0.01$ \\
\hline Crude protein & 173 & 166 & 0.1 & $<0.01$ \\
\hline Starch & 90 & 149 & 0.1 & $<0.01$ \\
\hline Neutral detergent fiber & 358 & 335 & 0.2 & $<0.01$ \\
\hline Indigestible neutral detergent fiber & 74 & 66 & 0.1 & $<0.01$ \\
\hline Protein balance in the rumen & 29.2 & 28.3 & 0.019 & $<0.01$ \\
\hline
\end{tabular}

${ }^{1}$ SEM: standard error of the mean 
The cows received formic acid as part of the PBP. Additionally, the silage contained a formic acid-based additive so that the daily intakes of formic acid were 154 and $194 \mathrm{~mL}$ (5.4 and $7.4 \mathrm{~mL}$ formic acid/ $\mathrm{kg}$ of TMR) per cow for the control and potato groups, respectively. The amount was somewhat higher for the potato group, but this was probably not a major factor affecting the outcomes of the experiment. Kara et al. [31] reported that no significant differences were observed between 4 and $8 \mathrm{~mL}$ of formic acid/ $\mathrm{kg}$ of TMR on ruminal fermentation parameters. Additionally, based on the recommendation from EFSA [32], the formic acid supply to cows was lower than the maximum proposed dose $(10,000 \mathrm{mg}$ $(8.2 \mathrm{~mL})$ of formic acid/ $\mathrm{kg}$ of TMR). Furthermore, considering the fast perishability of the potato by-product, it was necessary to extend the shelf life of this ingredient by using a formic acid-based preservative.

The apparent total-tract digestibilities estimated by using iNDF as an internal marker are presented in Table 5. The DM and OM digestibilities were greater $(p<0.05)$ in the diet with inclusion of PBP. No statistical differences $(p>0.05)$ were found for $C P$, starch and NDF digestibilities. The greater DM and OM digestibilities for the diet containing PBP were probably due to its higher starch content, which has greater digestibility, and at the same time, lower NDF content, which has lower digestibility. The digestibility values were low which is also highlighted by the lower diet ME concentration when estimated from $\mathrm{OM}$ digestibility compared to the one based on feed values. As a methodological challenge, incomplete recovery of iNDF leads to underestimation of the digestibility values, but it may still be assumed to detect the differences between the dietary treatments (see, e.g., Savonen et al. [17]).

Table 5. Apparent total-tract digestibility $(\mathrm{g} / \mathrm{g}$ ) of dietary components of the total mixed ration (TMR) diets in the dairy cow feeding experiment (Experiment 1$)$.

\begin{tabular}{ccccc}
\hline & Control TMR & Potato By-Product TMR & SEM $^{\mathbf{1}}$ & $p$-Value \\
\hline Dry matter & 0.642 & 0.673 & 0.0044 & $<0.01$ \\
Organic matter & 0.628 & 0.657 & 0.0039 & $<0.01$ \\
Crude protein & 0.553 & 0.553 & 0.0068 & 0.98 \\
Starch & 0.960 & 0.971 & 0.0042 & 0.11 \\
Neutral detergent fiber & 0.572 & 0.589 & 0.0109 & 0.30 \\
\hline
\end{tabular}

${ }^{1}$ SEM: standard error of the mean.

Starch degradation may vary according to its source, and thus the risk of acidosis should be considered when including potato in ruminant diets. Monteils et al. [33], comparing the ruminal degradation of wheat and potato starches, found that the concentrations of total VFA and ruminal $\mathrm{pH}$ were more variable for wheat than for potato in grass silagebased diets. Additionally, they identified that wheat can be completely replaced by potato in maize silage-based diets without risk of acidosis nor negative effects on digestion.

In our experiment, milk production in $\mathrm{kg} /$ day was lower $(p<0.05)$ for cows fed PBP, but the difference did not reach significance for ECM $(p=0.12)$, as the milk solids content was higher $(p<0.05)$ in the milk of cows receiving the PBP (Table 6). In contrast to our work, Onwubuemeli et al. [30] reported that milk production was not affect by incremental levels of wet potato processing waste up to $20 \%$ on a dry matter basis as a substitute for high-moisture maize in dairy cow diets. Literature results are very variable, as Mosavi et al. [10] reported minor decreases in milk production, while Tavares et al. [13] found slightly greater milk production and Eriksson et al. [11], Zunong et al. [12] and Jurjanz et al. [34] found no difference in the performance of cows fed potato by-product. The differences in responses are likely to be due to the quality of potato-based feed in relation to the dietary ingredients it is replacing in the diet, but in none of the experiments cited previously were clearly adverse effects detected. 
Table 6. Milk production, composition and efficiency of milk production of the dairy cows fed different total mixed rations (TMR; Experiment 1).

\begin{tabular}{ccccc}
\hline & Control TMR & $\begin{array}{c}\text { Potato By-Product } \\
\text { TMR }\end{array}$ & SEM $\mathbf{1}^{\text {T }}$ & $p$-Value \\
\hline Production per day & & & & \\
\hline Milk, kg & 38.2 & 35.8 & 0.61 & 0.03 \\
Energy corrected milk, kg & 40.1 & 38.6 & 0.64 & 0.12 \\
Fat, g & 1623 & 1588 & 33.1 & 0.47 \\
Protein, g & 1435 & 1363 & 15.8 & 0.01 \\
Lactose, g & 1716 & 1606 & 30.8 & 0.04 \\
\hline Milk composition, g/kg & & & & \\
\hline Fat & 42.5 & 44.2 & 0.56 & 0.06 \\
Protein & 37.8 & 38.3 & 0.28 & 0.25 \\
Lactose & 44.9 & 44.7 & 0.13 & 0.48 \\
Solids & 134.8 & 137.0 & 0.63 & 0.04 \\
\hline Urea, mg/100 ml & 31.0 & 28.5 & 0.68 & 0.03 \\
Nitrogen use efficiency & 0.293 & 0.313 & 0.0015 & $<0.01$ \\
Energy corrected milk, & 1.42 & 1.46 & 0.017 & 0.09 \\
kg/kg DM intake & & & & \\
\hline
\end{tabular}

${ }^{1}$ SEM: standard error of the mean.

Daily protein and lactose yields were lower $(p<0.05)$ for cows fed PBP (Table 6$)$, while no difference was found $(p>0.05)$ for fat production. The milk fat content tended to be higher $(p=0.06)$ while no statistical differences $(p>0.05)$ were found in milk protein and lactose concentration. The increased fat concentration may be linked to the higher starch content of the PBP diet and a similar effect was observed by Jurjanz et al. [34]. Jurjanz et al. [34] studied the effect of starch sources in dairy cow diets, such as wheat and potato peelings, and did not observe any effect on DM intake and milk production, but milk fat concentration was higher when potato peelings were fed at a higher starch concentration.

The slightly improved $(p<0.05)$ efficiency of nitrogen utilization in response to PBP inclusion merely reflects the decreased $\mathrm{CP}$ intake on that diet, as nitrogen use efficiency is directly related to CP intake [35]. No difference was found $(p>0.05)$ for energy-corrected milk in $\mathrm{kg} / \mathrm{kg}$ DM intake.

The reason for the reduced feed intake and milk production in response to PBP inclusion in the diet could not be unequivocally explained. Subjective observations during the experiment did not give reason to suspect hygienic problems of the PBP. In addition, no problem related to palatability was observed. Schneider at al. [36] emphasized that potato is a palatable alternative to dairy cows with approximately the same energy value as ground maize, at least when offered as a meal. The main difference between the diets was the higher starch intake of PBP-fed cows, but it did not impair fiber digestion and was still at a moderate level, so problems related to rumen acidosis, for example, should be unlikely.

Although milk production was slightly reduced, the economic output of the system depends on the costs of the feeds in relation to each other as well as milk price. A viable option would also be to use the by-product feeds in the diets of other livestock groups, such as growing cattle. The environmental benefits depend on the alternative uses of the by-product, but in general, feed use can be considered more useful than other uses, e.g., in soil amendment. The net food production efficiency can be improved by the use of non-human-edible by-products [37] and it can be assumed to improve the acceptability of livestock production. The use of by-products can also decrease the carbon footprint of animal products, but it is partly dependent on the allocation of $\mathrm{CO}_{2}$ equivalents to the main products and by-products. 


\subsection{Aerobic Stability of Total Mixed Ration and Potato By-Product (Experiment 2)}

The heating of TMR may be a serious practical problem as mixing various feed components provides inoculation, aeration and multiple substrates for microbes, accelerating spoilage, and moist by-products may be particularly challenging [38]. The chemical composition and microbial quality of the ingredients used to prepare the TMRs in the aerobic stability trial at laboratory-scale are presented in Table 7. The silage DM concentration used in the TMR recipes was slightly higher than in the dairy cow experiment, while the DM of PBP was similar. Starch and OM contents were higher in PBP than in silage and concentrate, while its contents of ash, $\mathrm{CP}$ and NDF were lower. The microbial quality parameters of PBP were closely comparable to those in the silage, except for lactic acid bacteria, which was higher in PBP. The presence of enterobacteria and molds were higher in the concentrate than in silage and PBP. Due to the low DM content of PBP, water was added in TMRs 1 and 2 (with lower inclusions of PBP) to be able to compare the TMRs at a similar DM level. The achieved DM levels were 356,352 and $385 \mathrm{k} / \mathrm{kg}$ for TMR1, TMR2 and TMR3, respectively.

Table 7. Composition and microbial quality of the feeds, and dry matter and $\mathrm{pH}$ of different total mixed rations (TMR) in the aerobic stability experiment (Experiment 2).

\begin{tabular}{cccc}
\hline & Silage & Concentrate & Potato By-Product \\
\hline Dry matter (DM), g/kg & 431 & 872 & 214 \\
$\mathrm{pH}$ & 4.33 & 6.51 & 4.52 \\
\hline In DM, g/kg & & & \\
\hline Ash & 93 & 88 & 44 \\
Crude protein & 134 & 237 & 80 \\
Starch & 6 & 177 & 737 \\
Neutral detergent fiber & 236 & 241 & 61 \\
Water soluble carbohydrates & 28 & 77 & 50 \\
\hline Microbial quality & & & $2.0 \times 101$ \\
\hline Enterobacteria, cfu 1/g & $<1.0 \times 101$ & $3.1 \times 103$ & $8.9 \times 107$ \\
Lactic acid bacteria, cfu/g & $5.4 \times 106$ & $4.4 \times 104$ & $1.4 \times 104$ \\
Aerobic bacteria, cfu/g & $2.9 \times 105$ & $3.0 \times 105$ & $<1.0 \times 101$ \\
Yeasts, cfu/g & $6.2 \times 104$ & $<1.0 \times 101$ & 3 \\
Molds, cfu/g & $1.0 \times 101$ & $8.2 \times 104$ & TMR3 \\
Clostridia, spores/g & 1.1 & 23 & 385 \\
\hline DM, g/kg & TMR1 & TMR2 & 5.14 \\
\hline pH & 356 & 352 &
\end{tabular}

${ }_{1}^{1}$ cfu: colony-forming unit.

There were no statistically significant interactions between the main effects in Experiment 2 such that the results are presented by the main effects in Table 8. To show the individual treatment effects for aerobic stability, Figure 1 is included. The effect of PBP inclusion on aerobic stability was quadratic $(p<0.05)$ (Table 8$)$ as it drastically reduced from TMR1 to TMR2 (117 vs. $58 \mathrm{~h}$ ) but further reduction in TMR3 was minor ( $54 \mathrm{~h})$. The addition of FPA linearly increased $(p<0.05)$ the aerobic stability of the TMRs. For the salt-based preservative, a quadratic pattern $(p<0.05)$ was observed, in which the improvement in aerobic stability was modest at low dose and greater at the high dose. Figure 1 shows that the responses to preservatives were greater in the most stable TMR1, and their efficacy decreased in the more challenging conditions of TMR2 and TMR3. A similar phenomenon was demonstrated by Seppälä et al. [39] using brewers' grains or low-quality ingredients to challenge the TMR stability. 
Table 8. Aerobic stability and losses, and visual spoilage of total mixed rations with incremental proportions of potato by-product (PBP) and treated with formic and propionic acid-based (FPA) or salt-based (Salt) preservatives (Experiment 2).

\begin{tabular}{|c|c|c|c|c|c|c|c|c|c|c|c|c|c|c|c|c|}
\hline & \multirow{2}{*}{\multicolumn{3}{|c|}{$\begin{array}{c}\text { PBP in } \\
\text { TMR, g/kg DM }\end{array}$}} & \multirow{3}{*}{ SEM $^{1}$} & \multicolumn{5}{|c|}{ Preservative Dose, $\mathrm{L} / \mathrm{t}$} & \multirow{3}{*}{ SEM $^{1}$} & \multirow{2}{*}{\multicolumn{6}{|c|}{$p$-Value ${ }^{2}$}} \\
\hline & & & & & \multirow{2}{*}{$\begin{array}{c}\text { Control } \\
0\end{array}$} & \multicolumn{2}{|c|}{ FPA } & \multicolumn{2}{|c|}{ Salt } & & & & & & & \\
\hline & 0 & 10 & 20 & & & 1.5 & 3 & 1.5 & 3 & & $\begin{array}{c}\text { PBP } \\
\text { L }\end{array}$ & $\begin{array}{c}\text { PBP } \\
\text { Q }\end{array}$ & $\begin{array}{c}\text { FPA } \\
\text { L }\end{array}$ & $\begin{array}{c}\text { FPA } \\
\mathbf{Q}\end{array}$ & $\underset{\mathrm{L}}{\text { Salt }}$ & $\begin{array}{c}\text { Salt } \\
\text { Q }\end{array}$ \\
\hline $\begin{array}{l}\text { Aerobic stability } \\
\left(2{ }^{\circ} \mathrm{C}\right) \text {, hours }\end{array}$ & 117 & 58 & 54 & 7.9 & 50 & 73 & 81 & 65 & 113 & 12.7 & $<0.01$ & $<0.01$ & $<0.01$ & 0.31 & $<0.01$ & 0.04 \\
\hline $\begin{array}{l}\text { Aerobic stability } \\
\left(3^{\circ} \mathrm{C}\right) \text {, hours }\end{array}$ & 137 & 79 & 61 & 10.6 & 56 & 84 & 95 & 78 & 150 & 14.3 & $<0.01$ & $<0.01$ & $<0.01$ & 0.21 & $<0.01$ & $<0.01$ \\
\hline $\begin{array}{l}\text { Aerobic losses, } \mathrm{g} / \mathrm{kg} \\
\text { fresh matter }\end{array}$ & 24 & 32 & 28 & 2.0 & 38 & 27 & 27 & 29 & 18 & 1.8 & $<0.01$ & $<0.01$ & $<0.01$ & $<0.01$ & $<0.01$ & 0.31 \\
\hline $\begin{array}{l}\text { First spot of } \\
\text { mold, hours }\end{array}$ & 160 & 117 & 117 & 9.4 & 96 & 125 & 136 & 136 & 163 & 12.2 & $<0.01$ & $<0.01$ & $<0.01$ & 0.35 & $<0.01$ & 0.50 \\
\hline $\begin{array}{c}\text { Complete } \\
\text { spoilage, hours }\end{array}$ & 282 & 221 & 256 & 13.9 & 197 & 221 & 267 & 248 & 331 & 12.1 & $<0.01$ & $<0.01$ & $<0.01$ & 0.02 & $<0.01$ & $<0.01$ \\
\hline
\end{tabular}

${ }^{1}$ SEM: standard error of the mean. ${ }^{2}$ PBP L: linear effect of potato by-product inclusion on TMR; PBP Q: quadratic effect of potato by-product inclusion on TMR; FPA L: linear effect of formic acid-based preservative dose on TMR; FPA Q: quadratic effect of formic acid-based preservative dose on TMR; Salt L: linear effect of salt-based preservative dose on TMR; Salt Q: quadratic effect of salt-based preservative dose on TMR.

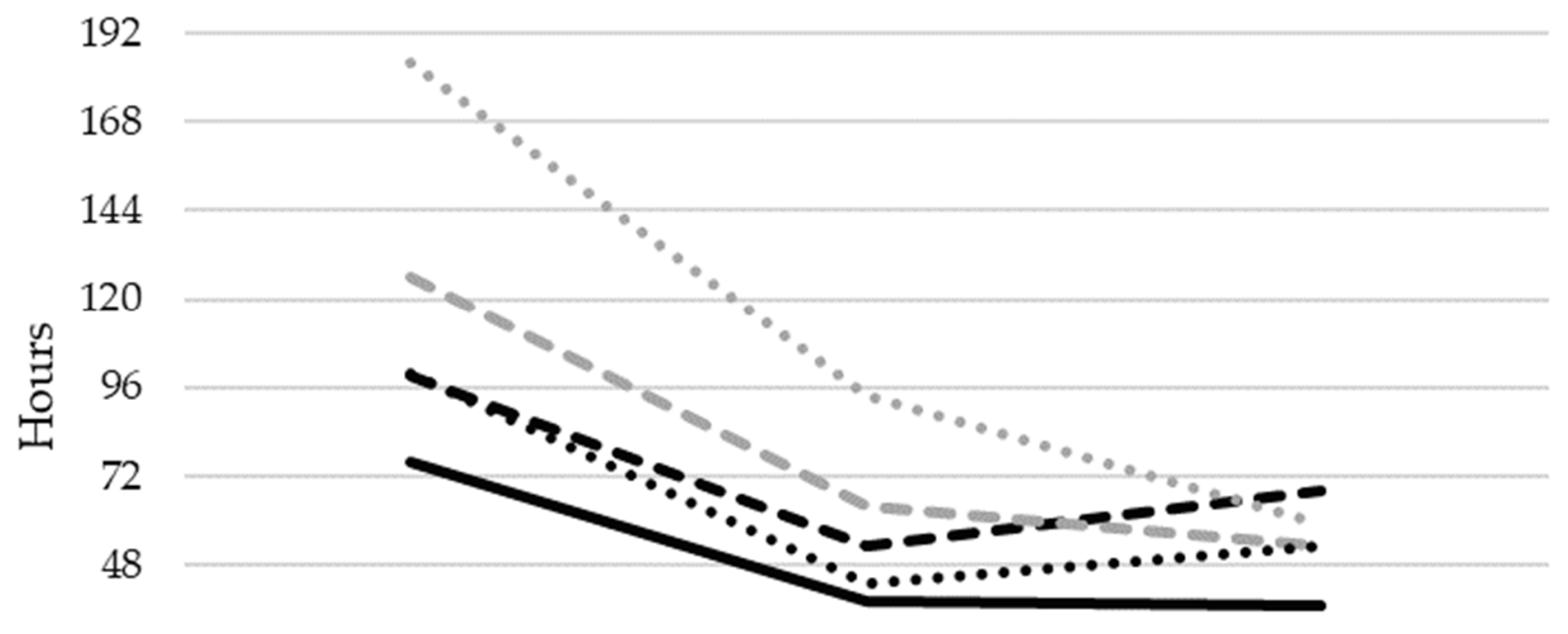

24

0

PBP0

PBP10

PBP20

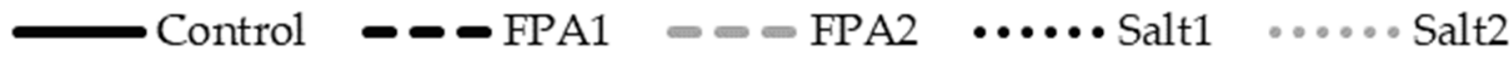

Figure 1. Aerobic stability $\left(2{ }^{\circ} \mathrm{C}\right.$ above room temperature) of total mixed rations with incremental proportions $(0,10$ or $20 \mathrm{~g} / \mathrm{kg}$ dry matter) of potato by-product (PBP) and treated with formic and propionic acid-based (FPA) or salt-based (Salt) preservatives at 1.5 (FPA1 and Salt1) or 3 (FPA2 and Salt2) liters per ton (Experiment 2).

The visually observed first spot of mold and complete spoilage were quadratically affected $(p<0.05)$ by the inclusion of PBP in the TMR. The TMR1 spoiled later than TMRs 2 and 3. Both preservatives improved $(p<0.05)$ the shelf-life of TMRs with increasing levels of PBP by delaying the first appearance of visible mold and complete spoilage.

The aerobic spoilage of the PBP as such and the effects of the preservatives were also evaluated (Figure 2). Both preservatives delayed $(p<0.05)$ the appearance of mold and complete deterioration of PBP, but Salt was more effective $(p<0.05)$ than FPA. Rinne et al. [15] also noticed a clear delay in visual spoilage of a moist carrot by-product in response to a formic acid-based preservative. Chemical preservatives seem to be efficient in preserving moist by-products and the clear dose response to chemical preservatives indicates that in 
case of spoilage problems in practice, increasing the dose is a recommended strategy. Some researchers have also successfully ensiled potato or other moist vegetable by-products mixed with higher DM feed components to alleviate the storage challenges $[13,40]$.

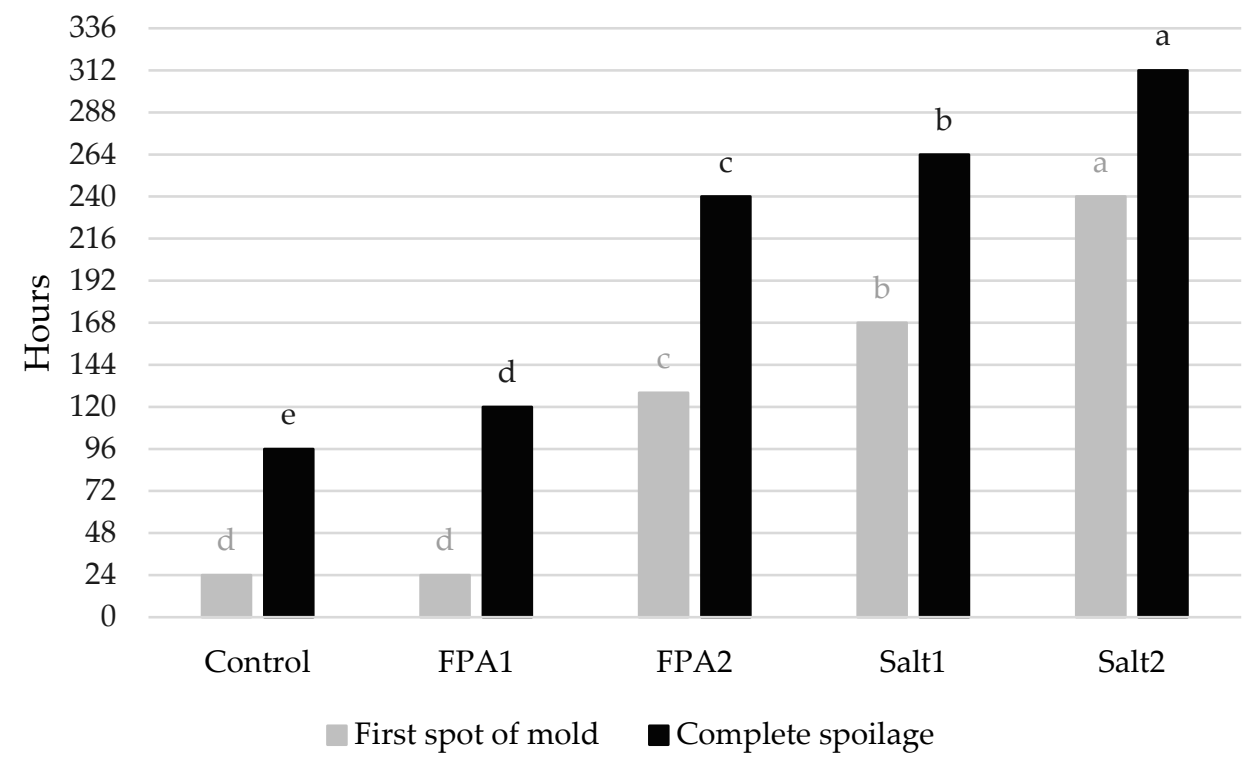

Figure 2. Aerobic spoilage by visual inspection of sole potato by-product treated with formic and propionic acid-based (FPA) or salt-based (Salt) preservatives at 1.5 (FPA1 and Salt1) or 3 (FPA2 and Salt2) liters per ton (Experiment 2). Values with different superscript letter within each parameter are significantly different at $5 \%$, Tukey test.

\section{Conclusions}

The inclusion of potato by-product in dairy cow diets at $135 \mathrm{~g} / \mathrm{kg}$ on a DM basis resulted in lower feed intake, but greater diet OM digestibility, possibly due to the greater starch content, which partly compensated for the lower intake. Consequently, only a minor reduction in some milk production parameters were observed. The inclusion of potato by-product reduced the aerobic stability of total mixed rations, and it could, to a limited extent, be improved by the addition of chemical preservatives. This experiment demonstrated that a potato by-product may successfully be incorporated into the diet of high yielding dairy cows and benefits in sustainability of the food-feed system can be achieved, although milk production may be slightly decreased.

Author Contributions: Conceptualization, M.F., E.J. and M.R.; methodology, M.F., P.M. and M.R.; formal analysis, M.F.; writing-original draft preparation, M.F. and M.R.; writing-review and editing, T.S., T.J., M.L., M.K., E.J. and P.M.; project administration and funding acquisition, E.J. All authors have read and agreed to the published version of the manuscript.

Funding: This research received financial support from the EU as part of the Circwaste project (LIFEIP IPE FI 004; http: / / www.circwaste.fi accessed on 21 April 2021). The views reflected within the content are entirely the project's own and the EU commission is not responsible for any use of them.

Institutional Review Board Statement: Ethical review and approval were waived for this study, due to non-invasive methods used in the animal experimentation.

Informed Consent Statement: Not applicable.

Data Availability Statement: For access of the original data, contact the authors.

Acknowledgments: The authors acknowledge the support of Kiviranta Company (Loimaa, Finland) for providing the potato by-product.

Conflicts of Interest: The authors declare no conflict of interest. 


\section{References}

1. Stenmarck, Å.; Jensen, C.; Quested, T.; Moates, G. Estimates of European Food Waste Levels; European Commission (FP7), Coordination and Support Action; IVL Swedish Environmental Research Institute: Stockholm, Sweden, 2016; Available online: https:/ / www.eu-fusions.org/phocadownload/Publications/Estimates\%20of\%20European\%20food\%20waste\%20levels.pdf (accessed on 21 December 2020).

2. Okonko, I.O.; Ogunnusi, T.A.; Aloysius, F.E.; Adejoye, O.D.; Adewale, O.A. Utilization of food wastes for sustainable development. Electron. J. Environ. Agric. Food Chem. 2009, 8, 263-286.

3. Halmemies-Beauchet-Filleau, A.; Rinne, M.; Lamminen, M.; Mapato, C.; Ampapon, T.; Wanapat, M.; Vanhatalo, A. Review: Alternative and novel feeds for ruminants: Nutritive value, product quality and environmental aspects. Animal 2018, 12, s295-s309. [CrossRef]

4. FAO. International Year of the Potato; FAOSTAT: Rome, Italy, 2008; Available online: http:/ / www.fao.org/potato-2008 (accessed on 16 December 2020).

5. FAO. Food Composition Database of Potato Varieties; FAO: Rome, Italy, 2009; Available online: http://www.fao.org/infoods/index_ en.stm (accessed on 16 December 2020).

6. $\quad$ van der Goot, A.J.; Pelgrom, P.J.M.; Berghout, J.A.M.; Geerts, M.E.J.; Jankowiak, L.; Hardt, N.A.; Keijer, J.; Schutyser, M.A.I.; Nikiforidis, C.V.; Boom, R.M. Concepts for further sustainable production of foods. J. Food Eng. 2016, 168, 42-51. [CrossRef]

7. Yacout, M.H.M. Anti-nutritional factors \& its roles in animal nutrition. J. Dairy Vet. Anim. Res. 2016, 4, 237-239. [CrossRef]

8. Bakshi, M.P.S.; Wadhwa, M.; Makkar, H.P.S. Waste to worth: Vegetable wastes as animal feed. CAB Rev. 2016, 11, 1-26. [CrossRef]

9. Ertl, P.; Zebeli, Q.; Zollitsch, W.; Knaus, W. Feeding of by-products completely replaced cereals and pulses in dairy cows and enhanced edible feed conversion ratio. J. Dairy Sci. 2015, 98, 1225-1233. [CrossRef] [PubMed]

10. Mosavi, G.H.R.; Fatahnia, F.; Alamouti, H.M.; Mehrabi, A.A.; Kohi, H.D. Effect of dietary starch source on milk production and composition of lactating Holstein cows. S. Afr. J. Anim. Sci. 2012, 42, 201-209. [CrossRef]

11. Eriksson, T.; Murphy, M.; Ciszuk, P.; Burstedt, E. Nitrogen balance, microbial protein production, and milk production in dairy cows fed fodder beets and potatoes, or barley. J. Dairy Sci. 2004, 87, 1057-1070. [CrossRef]

12. Zunong, M.; Tuerhong, T.; Okamoto, M.; Hongo, A.; Hanada, M. Effects of a potato pulp silage supplement on the composition of milk fatty acids when fed to grazing cows. Anim. Feed Sci. Tech. 2009, 152, 81-91. [CrossRef]

13. Tavares, V.B.; Pinto, J.C.; Barcelos, A.F.; Muniz, J.A.; Rezende, A.V.; Carvalho, J.R.R. Effects of addition of potato in elephant-grass silage on intake and production of dairy cows. Rev. Bras. Zootec. 2011, 40, 2706-2712. [CrossRef]

14. Eliyahu, D.; Yosef, E.; Weinberg, Z.G.; Hen, Y.; Nikbachat, M.; Solomon, R.; Mabjeesh, S.J.; Miron, J. Composition, preservation and digestibility by sheep of wet by-products from the food industry. Anim. Feed Sci. Technol. 2015, 207, 1-9. [CrossRef]

15. Rinne, M.; Franco, M.; Jalava, T.; Järvenpää, E.; Kahala, M.; Blasco, L.; Siljander-Rasi, H.; Kuoppala, K. Carrot by-product fermentation quality and aerobic spoilage could be modified with silage additives. Agric. Food Sci. 2019, 28, 59-69. [CrossRef]

16. Luke. Feed Tables and Nutrient Requirements. 2020. Available online: www.luke.fi/feedtables (accessed on 16 December 2020).

17. Savonen, O.; Franco, M.; Stefanski, T.; Mäntysaari, P.; Kuoppala, K.; Rinne, M. Grass silage pulp as a dietary component for high-yielding dairy cows. Animal 2020, 14, 1472-1480. [CrossRef] [PubMed]

18. AOAC. Official Methods of Analysis; Association of Official Analytical Chemists, Inc.: Arlington, VA, USA, 1990.

19. Somogyi, M. A new reagent for the determination of sugars. J. Biol. Chem. 1945, 160, 61-68. [CrossRef]

20. Salo, M.-L.; Salmi, M. Determination of starch by the amyloglucosidase method. J. Sci. Agric. Soc. 1968, 40, 38-45. [CrossRef]

21. van Soest, P.J.; Robertson, J.B.; Lewis, B.A. Methods for dietary fibre, neutral detergent fibre and nonstarch polysaccharides in relation to animal nutrition. J. Dairy Sci. 1991, 74, 3583-3597. [CrossRef]

22. Huhtanen, P.; Ahvenjärvi, S.; Weisbjerg, M.; Nørgaard, P. Digestion and Passage of Fibre in Ruminants. In Ruminant Physiology: Digestion, Metabolism and Impact of Nutrition on Gene Expression, Immunology and Stress; Sejrsen, K., Hvelplund, T., Nielsen, M.O., Eds.; Wageningen Academic Publishers: Wageningen, The Netherlands, 2006; pp. 87-129.

23. Huhtanen, P.; Nousiainen, J.; Rinne, M. Recent developments in forage evaluation with special reference to practical applications. Agric. Food Sci. 2006, 15, 293-323. [CrossRef]

24. McCullough, H. The determination of ammonia in whole blood by direct colorimetric method. Clin. Chim. Acta 1967, 17, 297-304. [CrossRef]

25. Haacker, K.; Block, H.J.; Weissbach, F. Zur kolorimetrischen Milchsäurebestimmung in Silagen mit p-Hydroxydiphenyl. [On the colorimetric determination of lactic acid in silages with p-hydroxydiphenyl]. Arch. Tierernähr. 1983, 33, 505-512. [CrossRef]

26. Huhtanen, P.J.; Blauwiekel, R.; Saastamoinen, I. Effects of intraruminal infusions of propionate and butyrate with two different protein supplements on milk production and blood metabolites in dairy cows receiving grass silage based diet. J. Sci. Food Agric. 1998, 77, 213-222. [CrossRef]

27. Franco, M.; Stefanski, T.; Jalava, T.; Kuoppala, K.; Huuskonen, A.; Rinne, M. Fermentation quality and aerobic stability of low moisture-crimped wheat grains manipulated by organic acid-based additives. J. Agric. Sci. 2019, 157, 245-253. [CrossRef]

28. Feedipedia. Animal Feed Resources Information System. 2020. Available online: https://www.feedipedia.org/ (accessed on 21 December 2020).

29. Lechartier, C.; Peyraud, J.-L. The effects of starch and rapidly degradable dry matter from concentrate on ruminal digestion in dairy cows fed corn silage-based diets with fixed forage proportion. J. Dairy Sci. 2011, 94, 2440-2454. [CrossRef] 
30. Onwubuemeli, C.; Huber, J.T.; King, K.J.; Johnson, C.O.L.E. Nutritive value of potato processing wastes in total mixed rations for dairy cattle. J. Dairy Sci. 1985, 68, 1207-1214. [CrossRef]

31. Kara, K.; Özkaya, S.; Erbaş, S.; Baytok, E. Effect of dietary formic acid on the in vitro ruminal fermentation parameters of barley-based concentrated mix feed of beef cattle. J. Appl. Anim. Res. 2018, 46, 178-183. [CrossRef]

32. European Food Safety Authority Scientific-EFSA. Scientific opinion on the safety and efficacy of formic acid when used as a technological additive for all animal species. EFSA J. 2014, 12, 3827. [CrossRef]

33. Monteils, V.; Jurjanz, S.; Colin-Schoellen, O.; Blanchart, G.; Laurent, F. Kinetics of ruminal degradation of wheat and potato starches in total mixed rations. J. Anim. Sci. 2002, 80, 235-241. [CrossRef]

34. Jurjanz, S.; Colin-Schoellen, O.; Gardeur, J.N.; Laurent, F. Alteration of milk fat by variation in the source and amount of starch in a total mixed diet fed to dairy cows. J. Dairy Sci. 1998, 81, 2924-2933. [CrossRef]

35. Huhtanen, P.; Nousiainen, J.; Rinne, M.; Kytölä, K.; Khalili, H. Utilization and partition of dietary nitrogen in dairy cows fed grass silage-based diets. J. Dairy Sci. 2008, 91, 3589-3599. [CrossRef]

36. Schneider, P.L.; Stokes, M.R.; Bull, L.S.; Walker, C.K. Evaluation of potato meal as a feedstuff for lactating dairy cows. J. Dairy Sci. 1985, 68, 1738-1743. [CrossRef]

37. Karlsson, J.; Spörndly, R.; Lindberg, J.; Holtenius, K. Replacing human-edible feed ingredients with by-products increases net food production efficiency. J. Dairy Sci. 2018, 101, 7146-7155. [CrossRef]

38. Seppälä, A. Controlling Aerobic Stability of Silage Based Total Mixed Rations. Doctoral Dissertation. Natural Resources and Bioeconomy Studies 45/2020. 62 P. +3 Appendices. 2020. Available online: https://jukuri.luke.fi/handle/10024/546250 (accessed on 26 December 2020).

39. Seppälä, A.; Heikkilä, T.; Mäki, M.; Miettinen, H.; Rinne, M. Controlling aerobic stability of grass silage-based total mixed rations. Anim. Feed Sci. Technol. 2013, 179, 54-60. [CrossRef]

40. Arco-Pérez, A.; Ramos-Morales, E.; Yáñez-Ruiz, D.R.; Abecia, L.; Martín-García, A.I. Nutritive evaluation and milk quality of including of tomato or olive by-products silages with sunflower oil in the diet of dairy goats. Anim. Feed Sci. Technol. 2017, 232, 57-70. [CrossRef] 